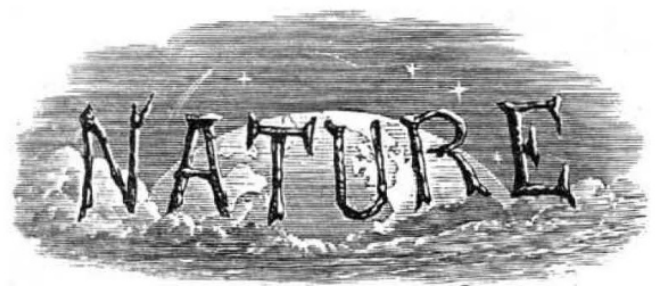

SATURDAY, MAY I9, I923.
PAGE

School and Sex

Science and Superstition of Primitive Mankind By Dr. B. Malinowski .

Modern Cosmogony. By Dr. Harold Jeffreys : 662

Military Mining

Our Bookshelf

Letters to the Editor:-

Adsorption and Hremoglobin.-Sir W. M. Bayliss, F.R.S.

The Complex Anisotropic Molecule in Relation to the Theory of Dispersion and Scattering of Light in Gases and Liquids.-Dr. Louis V. King

The Adhesive Apparatus of the "Sucking-fish." Sunder Lal Hora $\dot{0} \cdot \dot{*} \cdot{ }^{\circ}$

Vertical Change of Wind and Tropical Cyclones.-
S. K. Banerji

A Levitated Magnet. (With' Diagra' ${ }^{\circ}$ ) - F. $^{\circ}$. Harrison Glew .

Science and Economics.-Prof. Frederick Soddy, F.R.S. ; St. George Lane Fox. Pitt
Spermatogenesis of the Lepidoptera. - H. Graham Cannon Rodier System of Rat Repression.-Alfred E. Moore . . .

Active Hydrogen by Electrolysis. - Prof. A. C. Grubb - $\cdot$ A The Low-power Aeroplane or Aviette. By Prof. L.

The Earth's Electric and Magnetic Fields.-if. By

Prof. W. F. G. Swann

The Tercentenary of Sir William Petty : :

Obituary :-

Prof. E. W. Morley .

Sir Shirley Murphy

Mr. Joseph Wright

Mr. Sidney H. Wells

General E. A. Lenfant

Current Topics and Events

Our Astronomical Column

Research Items

The Italian Society for the Advancement of Science.

By Prof. John L. Myres

Industrial Paints and the Health of the Worker

The Duddell Memorial of the Physical Society. (Illustrated.)

The Ralph Forster Tablet at University College, London . . .

Cinema Film of the Total Eclipse of the Sun at

Wallal, Australia, September 21, 1922 .

University and Educational Intelligence .

Societies and Academies

Official Publications Received:

Diary of Societies

Editorial and Publishing Offices:

MACMILLAN \& CO., LTD.

ST. MARTIN'S STREET, LONDON, W.C.2.

Telegraphic Address: PHUSIS, LONDON.

Telephone Number: GERRARD 8830.

\section{School and Sex. ${ }^{1}$}

I 1920 the Consultative Committee of the Board of Education was reconstituted by Order in Council, and two urgent problems, of scientific character and far-reaching importance, were referred to it almost immediately for inquiry and advice: namely, first, what degree of differentiation is desirable; for boys and girls respectively, in the teaching of secondary schools ; and, secondly, what use can be made, in the public system of education, of psychological tests. . On the subject of the former reference the committee has received a vast body of evidence from a long list of witnesses-from medical men and psychologists, from teachers and examiners, from employers and business men; and the results of its inquiries have now been brought together in the pages of the report before us.

The first chapter, largely the work of the committee's secretary, Mr. R. F. Young, provides an admirable history of the curriculum in secondary schools for boys and girls ; and this brief chronological survey is followed by a descriptive account of the present system of secondary education, so far as it bears upon the terms of the committee's reference. The education of what was once considered to be the weaker or the gentler sex has passed through two opposite phases, and is entering upon a third. The first was a phase of emphasised sexdifference based upon a supposed sex-inequality. It was the stage of feminine accomplishments and nothing more ; it was also, therefore, a stage of educational inefficiency. During the second period-a period of reaction-education was based upon an assumed equality of the sexes; and reformers claimed, and endeavoured to secure, an identity of education for boys and girls, regardless of sex-difference. This, too; has not been entirely successful. The committee now discovers signs of a third stage-a stage which its own report will undoubtedly strengthen and reinforcewhich recognises that equality does not demand identity, and would allow the widest possible freedom for all individuals, no matter which their sex might be, to develop their special talents, and to prepare themselves for their future duties, according to the peculiar tastes and capacities of each.

It is, however, the central section of the report which will command the greatest scientific interest. Here the committee has collected together all the available evidence dealing with the physical and mental differences between boys and girls during the critical years of development.

The known facts regarding the anatomical and

1 Board of Education: 'Report of the Consultative Committee on Differentiation of the Curriculum for Boys and Girls respectively in Secondary Schools. Pp. xvi+193. (London: H.M. Stationery Office. 1923.) 2s. 9 d. net.

NO. 2794 , VOL. I I I ] 
physiological differences between the sexes are concisely summarised in a special appendix by Dr. J. G. Adami. The point of chief significance is the peculiarly rapid growth of the girls during the earlier phases of puberty. It is remarked that, as a consequence, the girl is almost adult while the boy is still adolescent. The memorandum ends by noticing that some of the most significant physiological differences are to be found in the activities of the glands of internal secretion; and, since recent research shows that these glands are intimately connected with emotional activity, this subtle physical difference is not without a deep psychological bearing.

As regards psychological differences generally, the committee has found that two opposing views appear to be entertained by various persons who have expressed opinions upon the subject. The first view maintains that "the higher the level reached in the development both of species and of individuals, the greater is the sex divergence" ; and concludes that "educationally the first and safest classification is that which is based upon sex." The second view insists that "sex is the cause of only a small fraction of the mental differences between individuals," the divergences of man from man, and of woman from woman, being far greater than those between one sex and the other.

The committee has reviewed the few scientific investigations carried out upon this problem both in England and in America, and has manifestly decided that the weight of the evidence is upon the side of the second of these alternative beliefs. It has been stated, upon statistical grounds, that the largest sex-differences are physical differences-differences in height, in weight, and in bodily strength. Intellectual differences are far smaller; and here again the wider divergences are discovered not upon the higher but upon the lower levels of the mind, namely, in processes involving simple sensory or motor activity, in sensation and in movement ; in the higher and more complex processes -in general intelligence and in ability to reason-the differences during the school period are extremely small. In memory and retentiveness, it is true, girls seem to surpass boys, and women to surpass men ; nor is this without an obvious educational bearing. But of all psychological differences the most significant are those that relate to temperament and character. It is the quality of her emotions which, in the mental sphere, chiefly distinguishes the woman from the man.

Thus, inborn sex-differences in mentality are far slighter than has been popularly assumed. On the other hand, the cumulative result of the emotional divergence, and still more of the difference in social functions, has resulted in wide separation of interest and outlook, which is only in a small degree innate and ineradicable, and is chiefly due to tradition, and to the varying play of educational influences, whether conscious or unconscious.

In actual educational attainments, the differences vary considerably according to the circumstances of teaching. Where boys and girls have been taught together in mixed schools, the differences may be barely discernible; but where they have been taught in distinct departments, there the divergence is wider. Such differences can be measured easily by means of standardised scholastic tests.

The chief ascertainable differences appear to be the following : boys are better at arithmetic, mathematics, physical sciences, classical languages, geography, and drawing; girls are better at reading, spelling, handwriting, English composition, English literature, and possibly history, modern languages, and biological sciences. Here very plainly the effects of interest and tradition are at work quite as much as constitutional differences of intellectual capacity. The part played by the two factors, however, can only be disengaged by further inquiry.

Indeed, the most suggestive paragraphs of the whole report are those in which the committee emphasises the need for further research. It is pointed out that the provisional conclusions arrived at rest mainly upon the casual impressions and subjective opinions of schoolmasters-men of considerable practical experience, but of little or no psychological training; and it is urged that there is both room and need for a widespread cooperative inquiry, in which strict scientific methods shall be employed, and in which teachers, psychologists, and medical men shall all take part.

\section{Science and Superstition of Primitive Mankind.}

The Golden Bough: a Study in Magic and Religion. By Sir James George Frazer. Abridged Edition. Pp. xiv +756 . (Macmillan and Co., Ltd., London, I922.) I8s. net.

CIR JAMES FRAZER'S "Golden Bough" is in $D$ many respects the greatest achievement of anthropology - a science the short life-history of which allows still of a rapid survey and a correct apportionment of values. The book, like no other work, expresses the spirit of modern humanism-the union of classical scholarship with folk-lore and anthropology. The marble forms of antique legend and myth are made to lend their beauty to the crude and queer customs of the savage and the uncouth usages of the peasant, while the Gods and Heroes of Olympus receive in exchange the vitalising breath of life and reality from their humbler yet more animate counterparts.

It is difficult to review a new version of the work in NO. 2794 , VOL. I I I ] 